\title{
'Simple Evidentiary' That Is Not Simple
}

\author{
M Fauzi ${ }^{1}$ \\ \{ fauzi.sh@gmail.com $\left.{ }^{1}\right\}$ \\ Faculty of Law, Universitas Mulawarman, Samarinda, Indonesia ${ }^{1}$
}

\begin{abstract}
The Simple evidentiary is mentioned in the three bankruptcy legal regimes that have been applied in Indonesia but there is no definition and no explanation of how to implement the simple evidentiary principle. This caused a controversy in both the practice and academic fields and raises diverse meanings of simple evidentiary system, including simple verification only with the judge's conjecture, simple without insolvency test, simple as a case of a request and not a contentious dispute case, and simple in the sense of an easy proof process based on strong evidence. A simple evidentiary system has put aside the condition of insolvent debtors as the main problem to be resolved. It will only reduce the possibility to resolve the insolvent debtor obligations through bankruptcy institutions. Bankruptcy institutions will only be a debt collection tool.
\end{abstract}

Keywords: bankruptcy, simple evidentiary, bankruptcy proceeding in Indonesia.

\section{Introduction}

Bankruptcy institutions are particular legal institutions. This characteristic gained its legitimacy from a special situation, the condition of an insolvent debtor so he could not pay his debts. This condition is the raison d'etre of the bankruptcy institution. The creditor's receivable face an unpaid risk because the debtor's assets are not enough to pay receivables from all the creditors (common-pool problems). This condition threatens the debtor's financial condition to become worse because it will compel each creditor to do a collective action to obtain payment for their respective receivables. Such a situation cannot be resolved through ordinary legal procedures because it will cause injustice. This condition requires an appropriate mechanism to deal with all debtors' obligations collectively based on the pari passu prorata parte principle to settle the debtor's liabilities. The system is known as a bankruptcy institution.

As a specialized legal institution, bankruptcy institutions have several characteristics that distinguish it from other legal institutions. In the initial stages of the process, the debtor has suffered his right to carry out legal actions against his property are under the general seizure. On the other hand, the creditors cannot execute their rights to receive payments from the defaulter. Whereas in the final stages of the bankruptcy process the debtor may lose all of his resources which must be liquidated to pay off for his liabilities. The creditor is not so lucky because his rights may be lost in part or in full, or diminished in value because they are forcibly converted into other forms. Based on these particular characters, then Axel Flessner called the bankruptcy institution as a drastic remedy[1]. Even as a lex specialist, bankruptcy law by law paralyzes other legal regimes that apply to normal situations, be they contract law, guarantee law, and company law while others refer to it as an improper billing procedure[2].

Bankruptcy law in its implementation changes some conditions of civil rights and liabilities of the parties. Various adjustments corresponding to Thomas H. Jackson and Robert E. Scott 
are an unavoidable consequence of a collective process. Without provisions that limit the rights and authority of the parties, the function of the bankruptcy institution as a collective process will not work properly[3]. But Charles W. Mooney suggested that adjustments generated by financial difficulties from debtors must be maintained to a margin to preserve the rights of each party proportionally[4]. This is proposed to uphold the rights and commitments of the parties as far as possible as well as the legal relationship between the parties.

The adjustments that take place in the bankruptcy process are not entirely related to the rights and commitments of the parties but also the procedural law of the bankruptcy process itself. One form of adjustment in the bankruptcy process in Indonesia is simple evidentiary principles. The three bankruptcy law regimes that once took effect in Indonesia emphasized that the process of verification of the debtors fulfilling the qualifications for being declared bankrupt must be done simply. However, the surprising thing is the three bankruptcy law regimes do not justify the simple evidentiary procedure. This lack of clarity raises many disputes in the application of simple evidence in the bankruptcy process. This paper will examine several aspects of simple evidentiary, particularly the legal establishment, its interpretation and the questions that arise in its utilization.

\section{Indonesian Bankruptcy Procedural Law}

Bankruptcy institutions are private legal institutions that intend to accomplish legal relations wherever possible between creditors and debtors in difficult financial situations[5][6][7]. According to Randy E. Barnet the differentiation of types of legal norms is at least based on four aspects of legal regulation: The four aspects are the substantive norms used, the position and status of legal subjects, the status of legal subjects who can file legal remedies, and the types of institutions given authority[8]. If the law and bankruptcy institution are seen using the Randy E. Barnet approach, the bankruptcy institution is in the private jurisdiction. The position of bankruptcy institutions as private legal institutions can be inferred from the substantive norms used, the mechanism of initiation, the criteria of the parties involved, the processes and authorities had by the parties and the relationship between the outcome of the process to the interests of the parties. This is in line with the view that Charles W. Mooney called bankruptcy institutions a "bankruptcy as a civil procedure" that enforces civil law as the substantive law[4]. As a procedural law that enforces material law, the goal to be achieved is to protect the interest of the parties that have legal relations in private law areas.

The three Indonesian bankruptcy law regimes embodied the same principle. The provisions in Faillissements-Verordening do not explicitly state that the applicable rule in the bankruptcy process is a civil procedure law. However, it stated that some special processes in bankruptcy are carried out under civil procedural law (Article 20, Article 32a, Article 65 (3), Article $118 \mathrm{a}$ (4)). Article 284 (1) Government regulation in lieu of law number 1 of 1998 on Amendment to the Law on Bankruptcy expressly stipulates that civil procedural law that applies also applies to Pengadilan Niaga, unless otherwise stipulated by law. Likewise, Article 299 of Law Number 37 the Year 2004 on Bankruptcy and Postponement of Obligations of Debt Payments stipulates that the applicable procedural law (in bankruptcy proceedings) is the Civil Procedure Code unless specified otherwise in the Act.

The foundation of the evidentiary system in Indonesia civil law is based on article 163 Herzien Inlandsch Regulations (HIR). The provision stipulates that "Whoever claims to have rights to an item, or designates an event to confirm his rights, or denies the rights of others, then 
that person must prove it". The burden of proof of the plaintiff is to prove the arguments or events that can support the lawsuit filed while the burden of proof of the defendant is to prove his denial of the arguments submitted by the plaintiff. The judge should not execute the principle of burden of proof literally. Judges should be wise in putting the burden of proof. Proof of evidence which may be used to affirm a person's rights or to object to the rights of others, as mentioned in the subsequent provision (Article 164 HIR), comprises written evidence, evidence of witnesses, conjecture, the confession, and an oath.

According to Yahya Harahap, the evidentiary law adopted in the Indonesian legal system is a closed and limited system in which the parties do not have the autonomy to submit the type or form of evidence in the case settlement process. Anything that is a legitimate and valuable as evidence has been expressly determined by the Law. The judge cannot accept whatever the parties propose as evidence. If the litigant party proposes evidence other than the provisions stipulated in the law, the judge must reject and exclude the evidence[9].

\section{Simple Evidentiary in Indonesian Bankruptcy Procedural Law}

One form of adjustment in the bankruptcy process in Indonesia is the use of simple evidentiary principles. The three bankruptcy law regimes that have prevailed in Indonesia emphasize that the process of proving that debtors have met the requirements for being declared bankrupt must be done simply. Article 6 paragraph (5) Faillissements-Verordening stipulates that bankruptcy statements are carried out if it can easily be concluded that from the events and circumstances it turns out that the defaulter cannot pay off his debt and there has been a bankruptcy request from the creditor as well as collection efforts proposed by the creditor. This provision determines that a simple evidentiary is made of the occurrence of events or circumstances that show that the debtor cannot pay his debts and the existence of a bankrupt application from the creditor as well as the collection proposed by the creditor. However, the provisions in Faillissements-Verordening do not provide an explanation of the conception of summary evidence, being unable to pay, and in a state of stop paying. Thus, the court indirectly has the sovereignty to consider the application for bankruptcy statements and is not bound by the evidentiary system and evidence specified in the civil procedure law as stipulated in Article 164 Herzien Indonesis Reglement (HIR), Article 248 Rechtsreglement Buitengewesten (Rbg), and Article 1866 Burgerlijk Wetboek[10]. The provision of Article 6 paragraph (5) Faillissements-Verordening provides sufficient flexibility with the judge to investigate and conclude a bankruptcy case.

Article 6 paragraph (3) of the Government Regulation in lieu of Law Number 1 Year 1998 concerning Amendments to the Bankruptcy Law states that the application for bankruptcy statement must be granted if there are facts or circumstances which simply prove that the requirements for bankruptcy as referred to in article 1 paragraph (1) has been satisfied. Based on this provision, a simple evidentiary is carried out of the conditions relating to the preconditions for a bankruptcy statement application, the existence of two or more creditors, the debtor has not paid for one creditor, and the existence of a debt that has been due and can be collected. But regarding what is meant by simple evidentiary not explained. Explanation of article 6 paragraph (3) only explains that what is meant by simple evidentiary is commonly referred to as summarized evidentiary. Judges are required to declare bankrupt debtors if the conditions as specified in Article 1 paragraph (1), and Article 6 paragraph (3) have been satisfied. This is intended to emphasize the nature of bankruptcy institutions as a simple, fast 
and efficient judicial process. The judge is faced with a limited area of consideration and the time in deciding the status of the debtor. Even though the development of the transaction mechanism makes the process of proving accounts receivable more complicated so it requires a high level of accuracy and requires more time to examine it.

Faced with this problem, the National Working Meeting of the Mahkamah Agung in September 2002 tried to formulate a simple evidentiary in bankruptcy institutions. The National Working Meeting concluded that bankruptcy institutions were the process of examining petition cases so they did not recognize the existence of exceptions, answers, replications, and conclusions as well as in dispute (contentious) cases between parties. Therefore, proof in bankruptcy cases is unilateral. Examination of bankruptcy applications by the Panel of Judges focuses on verification of two things, the relationship between creditors and debtors where the debt has become due and can be collected and the relationship between the debtor and separate creditors.

The conclusion of the National Working Meeting of the Mahkamah Agung was then included in Law 37 2004. Explanation of Article 8 paragraph (4) of Law 372004 states that what is meant by circumstances or conditions that are simply proven is the fact of two or more creditors and the fact that debts have matured and are not paid. While the difference in the amount of debt argued between the petitioner and the debtor does not prevent the decision of the bankruptcy statement. It is not yet known why the formulation of bankruptcy institutions as a process of examining application cases so that the evidence is unilateral and recognizes none exceptions, answers, replicates, duplicates, and conclusions as well as in contention cases between parties, not included in the formulation in Law 37 2004. Requirements for bankruptcy statements in Article 2 paragraph (1) of Law No. 37 of 2004 is a Debtor having two or more creditors and does not pay off at least one debt that has due and can be collected. Then Article 8 paragraph (4) stated that "Application for bankruptcy statement must be granted if there is a fact or condition which is simply proof that the requirements for bankruptcy have been fulfilled". Explanation of Article 8 paragraph (4) states that what is meant by a fact or condition that is simply proven is the fact that two or more creditors and the fact that the debt has matured and is not paid, while the difference in the debt's amount argued by the Applicant and debtor does not prevent the issuance of a Decision on Bankruptcy Statement.

The principle of simple evidentiary is not identified in legal systems in other countries, especially in bankruptcy. Similar provisions in bankruptcy law can only be established in Faillissementswet as bankruptcy law in the Netherlands. It is stated in Article 6 point 3 that a bankrupt decision will be imposed if based on the summierlijk blijkt (brief investigation) found that the debtor has not paid the debt that is due and can be collected. However, there is no further explanation of how the summierlijk blijkt was carried out. The principle of simple evidentiary also cannot be equated with the summary proceeding (summary judgment) as a simple judicial system made specifically for cases involving only two parties and small bill value.

\section{The Complexity of 'Simple Evidentiary'}

It was explained previously that, despite emphasizing a simple process of proof, the three bankruptcy law regimes did not explain what and how simple evidentiary must be carried out. Even though the judges made the simple evidentiary as one of the basic criteria for granting or rejecting the filed for bankruptcy statement submitted, besides fulfilling other requirements. The absence of clear criteria regarding this simple proof gives raises diverse meanings to the 
principle, including simple verification only with the judge's conjecture, simple without insolvency test, simply by not recognizing the stages of exception, answer, replication, conclusion, and simplicity in terms of easy proof based on strong evidence.

The term simple evidentiary in Law NO. 37 of 2004 is not only related to proving the fact there are at least two creditors and debts that are due that have not been paid. Article 127 stipulates that the examination of debts that are denied and cannot be reconciled must also be examined in a simple manner. With a creditor requesting a pairing of the receivables not present at the prescribed hearing, the concerned person is deemed to have withdrawn his request and if the rebuttal party is not present at the hearing, the judge is deemed to have denied the claim (paragraph 4). The simple criteria are also required on the grounds that the debtor has denied his debt and rank as stipulated in Article 132. Explained in paragraph (4) that the rebuttal does not mention reasons or rebuttal not addressed to all receivables but does not explicitly state recognized parts or disputed parts, is not considered a rebuttal. Thus it can be concluded that the definition of a simple examination in these provisions is a simplification of the taking of conjectures by the judge based solely on the facts available.

The meaning of another simple evidentiary conception is simple in the sense that things that need to be proven are only the fact that there are two or more creditors and there are debts that have matured and that are not paid. Proof of whether the debtor is the solvent or insolvent debtor, which is generally used as the basis for determining the debtor's financial stats, is not required so need not to be proven. The inability of the debtor to pay is sufficiently evidenced by the non-payment of debts that have matured and the existence of other creditors. Proving that debtors in insolvent conditions are generally considered as being not simple because the calculation of balance sheet over the total value of assets and the total value of debtors' liabilities is difficult and time-consuming. If the insolvency test based on the balance sheet must be verified, it will cause the bankruptcy examination process being not simple. This meaning is not appropriate because the bankruptcy law itself does not make insolvency tests a condition in the application for bankruptcy statements.

Another meaning of the principle of simple evidentiary is simple in the sense of bankruptcy process is an examination of requests case. The trial of bankruptcy application is unilateral because the judge's position is only to hear, assess, and conclude the petition and evidence proposed by the applicant. The judge in the bankruptcy hearing is not obliged to listen to the statement of the defendant. This interpretation is based on the results of the National Working Meeting of the Mahkamah Agung in September 2002 which formulated that a simple aspect of the process of evidentiary in bankruptcy was based on the construction of bankruptcy institutions as a process of an examining requests case. Therefore, the process of proof in bankruptcy cases is unilateral and recognizes none exceptions, answers, replicates, duplicates, and conclusions as with contention case. This formula emphasizes simple aspects in a short and simple process. This kind of meaning is not in line with Article 8 paragraph (1) of Law 37 of 2004 which requires judges to call on debtors if the application for a bankruptcy statement is submitted involuntarily by a party other than the debtor himself. Even for voluntary bankruptcy statements, judges may also call creditors to make sure that the application meets the bankruptcy requirements of the debtor. The judge in principle must hear from both parties to examine the evidence of a debt relationship between the creditor and the debtor where the debt has matured and can be billed as well as the relationship between the debtor and other creditors.

Another meaning of the principle of simple evidentiary is that easy to prove the fulfillment of the requirements of the bankruptcy of the debtor because based on evidence that has a binding position and compelling proof value and cannot be denied by the opposing party. If the evidence presented is irrefutable, the process of examining the case comes more concise because there is 
a slight possibility of arguments and counter-evidence. The judge will more easily conclude rights and obligations based on substantial evidence. There are no loopholes and weaknesses in judges' consideration in determining the bankruptcy status of the debtor. Even the decisions made are not easily disputed because they have been based on substantial evidence. The parties will be more circumspect when submitting a bankrupt statement or against a bankrupt decision without substantial evidence[10]. Indirectly this view considers that the application for bankruptcy statements cannot be based on weak evidence. This view emphasizes the effective aspects of evidence so that the process of verification becomes simple.

The various meanings of the simple evidentiary mentioned above are actually on the same path, a brief examination process. If the examination and verification of the bankruptcy statement application are based solely on the judge's judgment, without a balance sheet insolvency test, without a contradictory trial mechanism and only based on strong evidence, the examination process can be carried out briefly. However, even though the construction of the bankruptcy inspection system with simple evidentiary seems technically logical, it is not in line with the philosophical foundation of the bankruptcy institution as a manism to settle the obligation of insolvent debtors. Such a proof system also does not provide legal certainty and protection, not only to creditors but also to debtors.

If the criteria for granting a bankruptcy statement application are only based on evidence that is judged (unilaterally) strongly, then the application for bankruptcy statements based on what is judged (unilaterally) weak will invariably be rejected because it opens the opportunity for the opposing party to argue. This is discrimination against small creditors because strong evidence is generally only made for large-value transactions. Thus, creditors who have small bills will find it difficult to access bankruptcy institutions.

The system of proof in civil law provides the relative nature of the value of proof of all evidence. There is no absolute evidence that can close and negate evidence from the other party. All evidence still provides an opportunity to submit counter-proof. Even authentic deeds can lose their value of proof if counter-evidence can establish facts that are contrary to what is stated in the authentic deed. Even though one party does not have direct evidence of the arguments he proposed so it must be based with evidence of conjecture, or indeed when there is no evidence at all so it must determine through the oath, it can be the justification of arguments he proposed. Thus, the evidentiary value of all evidence in civil law depends on the will of both parties. The value of evidence in civil procedural law cannot be determined by the judge merely by being presented before the judge. The value of proof of a piece of evidence very depends on the opposing party does what against the evidence presented.

Based on the evidentiary system of civil law, exclusively in relation to the principle of simple evidentiary in the bankruptcy process, most verification process in bankruptcy cases will invariably be of a non-simple nature. Every creditor has an interest in obtaining full reimbursement for his bill and does not wish the financial difficulties experienced by the debtor to impact his rights. Likewise, debtors who seldom wish to have bankruptcy status refute the bankruptcy petition filed against him. Each party will perform under its interests. Thus the situation where there is no objection to a petition for a bankrupt statement is certainly improbable to take place. This means that there is a limited circumstance that the process of verification and examination of a bankruptcy statement application can satisfy the criteria for a simple evidentiary basis. All applications for bankruptcy statements will be rejected because they do not meet the simple evidentiary principle. Therefore, the mechanism and evidentiary value of the evidence within the relative civil procedural law cannot the basis for assessing the simplicity or failure of a bankruptcy verification process. Therefore, relativity from the simple 
or not the process of evidentiary in the bankruptcy process should not be a basis for deciding to grant or reject an application for a bankruptcy statement.

The issue regarding the principle of simple evidentiary is progressively problematic when encountered with the improvement of varieties of transactions and legal relations that are constantly expanding and progressively complex so that the legal relationship between the parties is can't easily be defined. The process of proving the existence of a debt relationship becomes increasingly complicated and not simple. As a result, the chances of a bankruptcy statement being proposed to be examined and accepted by a Commercial Court judge are less likely. Limited access to bankruptcy institutions as a mechanism for resolving financial difficulties experienced by debtors will not only have a negative impact on the parties but also can undermine the economic system. The absence of clear guidelines regarding the technicality and scope of simple evidentiary also resulted in a variety of meaning and application of the principle of simple evidence by the judge. The difference between the meaning and application of the principle of simple evidentiary by the commercial judge resulted in the disparity of judges' decisions both horizontally between the Commercial Courts and vertically between the Commercial Court, the Cessation level and at the level of the Judicial Review. This condition can cause legal uncertainty and reduce the legitimacy of the Commercial Court.

\section{Conclusion}

The principle of simple evidentiary is irrelevant to be used in the examination of requests for bankruptcy. The variety of transactions and legal relationships that continue to expand are difficult to determine. The consideration of granting or rejecting an application for a bankruptcy statement should not be based on the simplicity of the process of examination and verification of an application for a bankruptcy statement. The consideration for granting or rejecting a petition for bankruptcy statement should be emphasized on bankruptcy conditions, one of which is the condition of insolvent debtors. If in the application's examination for a bankruptcy statement it is confirmed that the debtor has a debt to two or more creditors and the evidence indicates that the debtor is in an insolvent condition, thus for the sake of law the debtor should be bankrupt. If the debtor is not bankrupt, it will contribute to unfairness in resolving the debtor's obligations to his creditors. This situation not only harms debtors and creditors but indirectly can also have a negative impact on society. 


\section{References}

[1] J. S. Ziegel, Current Developments in International and Comparative Corporate Insolvency Law. Oxford: Clarendon Press, 1994.

[2] "Hukum Kepailitan Dinilai Reduksi Hukum Jaminan Kebendaan," 2014. [Online]. Available: http://www.hukumonline.com/berita/baca/lt531eb1cff17ac/hukum-kepailitan-dinilai-reduksihukum-jaminan-kebendaan.html.

[3] T. H. Jackson and R. E. Scott, "On the Nature of Bankruptcy: An Essay of Bankruptcy Sharing and the Creditor' s Bargain," Va. Law Rev., vol. 75, no. 2, pp. 155-204, 1989.

[4] C. W. Mooney, "A Normative Theory of Bankruptcy Law: Bankruptcy As ( Is ) Civil Procedure," Wash. Lee Law Rev., vol. 61, no. 3, pp. 931-1061, 2004.

[5] A. Keay, "Insolvency Law: A Matter Of Public Interest?," North. Irel. Leg. Q., vol. 51, no. 4, pp. 509-534, 2000.

[6] V. Finch, “The Measures of Insolvency Law," Oxf. J. Leg. Stud., vol. 17, no. 2, 1997.

[7] W. Lucy, Philosophy of Private Law. New York: Oxford University Press, 2007.

[8] R. E. Barnett, "Four Senses of the Public Law-Private Law Distinction," Harv. J. Law Public Policy, vol. 9, no. 2, pp. 267-276, 1986.

[9] Y. M. Harahap, Hukum Acara Perdata Tentang Gugatan, Persidangan, Penyitaan, Pembuktian, dan Putusan Pengadilan. Jakarta: Sinar Grafika, 2012.

[10] Z. Asikin, Hukum Kepailitan dan Penundaan Pembayaran di Indonesia. Jakarta: Raja Grafindo Persada, 2001. 